\title{
Consciously eco-conscious: An eco-conscious re-reading of Bibhutibhushan Bandyopadhyay's Moon Mountain as young adult literature
}

\author{
Narendiran $S^{1}$ and Dr. Bhuvaneswari $\mathrm{R}^{2}$ \\ ${ }^{1}$ Research Scholar, School of Social Sciences and languages, Vellore Institute of Technology, \\ Vandalur - Kelambakkam Road, Chennai-6oo127, Tamilnadu, India \\ Email:narendiranı@gmail.com \\ ORCID iD: https://orcid.org/oooo-ooo2-9280-9178 \\ ${ }^{2}$ Assistant Professor (Sr.), School of Social Sciences and languages, Vellore Institute of \\ Technology, Vandalur - Kelambakkam Road, Chennai-6oo127, Tamilnadu, India. \\ Email: bhuvanadoss@yahoo.co.in \\ ORCID iD: https:// orcid.org/oooo-ooo3-466o-7118
}

\begin{abstract}
A better physical environment is quintessential for a comfortable life; this conscious of environment has been one of the post-world-war effects. The predominance of colonialism is accompanied by exploitation of forest and environment. Since then, land is nothing more than a resource that conferred wealth and materials for the colonizers. The depletion of forest for agriculture and urban development is a historical phenomenon. It is then aggravated by industrial revolution and colonization. The legacies of colonialism have influenced the mindset of the colonized. Recently, the scarcity of the resources and climate change are the rising concerns of the world. This is mainly because of the humans' insensitivity towards nature and literature plays an effective role in spreading the need for being eco-conscious. This article highlights the role of young adult narratives in spreading social awareness and interprets the classic Indian young adult novel Moon Mountain by Bibhutibhushan Bandyopadhyay, which has symbolic references offering ecological insights. The journey of the protagonist through the African continent is critiqued to highlight the enfeeble consciousness about the natural ecology of an individual who seizes material development. This study partly brings out how the colonial legacies continues to influence the contemporary environmental challenges and discusses the literary relationships between nature and youth influence readers' attitudes towards the contemporary anxieties such as climate change and related environmental crises.
\end{abstract}

Keywords: Eco-consciousness, Habitat, Young, Adult, Environment, Nature

\section{Introduction}

Eco-consciousness relates to being aware or concerned about environmental impacts and the ecosystem. Consciousness towards environment gained importance only after World War II. Ecoconsciousness stems from a threat posed to human beings' very existence on earth. Writings associated with environmental consciousness began from this period. During the Romantic period, nature poets such as Frost, Wordsworth, Shelley, Tennyson, and Keats, adorned nature in their works. In their admiration to nature, they linked environment with their personal experiencesuch as nostalgia, melancholy-and connected philosophies with an individual's inner thoughts. Later, around 1970s, works which were previously human-centred began to expand their boundaries

(c) AesthetixMS 2021. This Open Access article is published under a Creative Commons Attribution Non-Commercial 4.0 International License (http://creativecommons.org/licenses/by-nc/4.o/), which permits non-commercial re-use, distribution, and reproduction in any medium, provided the original work is properly cited. For citation use the DOI. For commercial re-use, please contact editor@rupkatha.com. 
and became interdisciplinary by including ecology and ecosystem along with the philosophical aspects of the environment.

The efforts of humans to meet their ambitious needs of progress were simply unsustainable, making environmental crisis the problem of the new millennium. According to Gro Harlem Brundtland (1987), we have already overdrawn the environmental resource accounts: "the results of the present profligacy are swiftly closing the options for future generations" (p. 24). The natural resources are not exclusive for a generation; they have been handed over from the past generation. The present generation must transmit them in good, and even enhance condition to posterity. The youth has to be made aware of issues such as global warming, resource shortage, species extinction, and the present status of crisis. They should be made conscious of sustainable methods to prevent and protect the environment. The nature must be preserved not only in an anthropocentric view but also for biocentric reasons.

This paper attempts to trace the growing insensitivity of humans towards nature through Moon Mountain (2009), a young adult adventure novel. The author's projection of the protagonist's aspirations and desire is glammed up with the colonial ideology, which is predominantly anthropocentric. The protagonist's journey through the landscape is analysed to describe the fading aesthetic consciousness of Shankar and the engulfing colonial ideas.

\section{Objective: Theoretical Understanding of Moon Mountain}

Moon Mountain (2009) is the English translation of a young adult Bengali novel Chander Pahar (1937), written by Bibhutibhushan Bandyopadhyay, a versatile Bengali writer. It is translated into English by Pradeep Sinha in the year 2009. The novel details an ordinary boy's dream and aspirations to go to the unexplored new continent (Africa). Bandyopadhyay's fundamental understanding of young minds has made his work more real and rational rather than fictional with supernatural elements. The key reason for choosing an adventure novel like Moon Mountain for an eco-conscious study owes to its setting, which is Africa, the ecological hotspot of the world. Further, the protagonist's adventure through the bio-geographic region and his encounter with strange and exotic landscapes, dangerous animals and natural calamities are other reasons that stress to critique the fiction for inducing eco-consciousness among the readers.

"This was that Africa, the dark, undiscovered continent, the land of gold, diamond country. How many unknown tribes and landscapes, unseen and unheard birds and animals lay hidden in those boundless tropical forests?” (Bandyopadhyay, 2007, p.15)

In specific, the Rwenzoris are the legendary "Mountains of the Moon.”These mountains are the highest and most permanent source of the River Nile and the largest water catchment areas, with over 40 permanent streams originating from them and twenty lakes scattered within; it also offers a unique and pristine landscape. The combination of spectacular snow-capped peaks, glaciers, $\mathrm{V}$-shaped valleys, fast flowing rivers with magnificent waterfalls and clear lakes make the area exceptionally scenic and beautiful.

The Rwenzoris' altitudinal range, its constant temperature, and extreme insolation support the richest montane flora in Africa, studded with many endemic species of Albertine Rift. This place is UNESCO's world heritage centre since 1994 and Ramsar site since 2009. WWF (the global conservation organisation), Uganda Wildlife Authority (UWA), and the Congolese Institute for Nature Conservation (ICCN) have jointly organised a survey to collect information on the changes in the glaciers and its implication on high-altitude wetlands. According to the team, the glacier has 
shrunk by $75 \%$ in the last century, and "Africa is at the risk of losing its central African glacier-the highest and permanent source of water to the River Nile" (Mumba, 2008, p.). This statement further supports the point of selecting Chander Pahar for an eco-critical study. Further, it emphasizes how indispensable it is to educate and create awareness among the young generation about the physical environment.

In fact, Bandyopadhyay did not travel to Africa. Instead, his richness of narration about Africa comes from many real accounts of explorers such as Mungo Park, Henry Morton Stanley, David Livingstone, Richard Burton, and others. He has also drawn from Wide World Magazine and other literary or journalistic sources. His narrative competency is evident in that these data have not intervened in the narration. (Dalai, 2011,) Though Chander Pahar is fictional, it is drawn from real incidents, which make the work more realistic, and Bandyopadhyay's understanding of young minds has made this book a typical work of young adult literature. Young adult literature is often an underestimated or underappreciated term in the literary canon, but young adult novels has gained momentum, with the genre drawing the critical consideration it warrants. It is not entirely a new genre in world literature, but the term YA and it being used as a label by the publishing houses in the market has created disagreement among literary critics. "Young adult literature" found common usage in the late 1960s, and though it deals with the reality and problems of young adults, these books are issued under the children's books division. Young Adult Library Services Association (YALSA) contributed a lot to the fame of young adult literature, and YA has seen massive growth in the West.

In India, YA was a new term until publishing houses such as Penguin Books Zubaan, India Ink, Rupa \& Co deluged the market with YA books. The 21st century saw a surge of successful YA writers such as Ranjit Lal, Paro Anand, Nilima Sinha, Amish Tripathi and others. According to Cindy Lou Daniels, (2006) it "is not to say, of course, that significant works categorized as YA have not been out there, only that contemporary works that have been labelled as YA tend to be ignored by many serious literary critics." In the same way, many great writers like Tagore, Premchand, Bibhutibhushan Bandyopadhyay and Devakinanadan Khatri have also written novels in their regional language that fall into this category. Bibhutibhushan Bandyopadhyay has contributed a lot to Bengali "Kumara-Sahitya" and as a travel narrator he has, "responded to several fundamentals of Romantic project: the fertility of unprogrammed and nonchalant itinaries, the suggestive magic of distance and wilderness, the excitement of tactile engagement, the equation of strangeness with authenticity." (Chakravarty, 2003) As such, Chander Pahar is an exponent example of India's early contribution to the young adult readership. Through the protagonist, the author has exercised the young adult aspect, such as "a thirst for the unfamiliar and the unknown... and zeal for adventure and lands beyond the horizon" (Dalai, 2011).

\section{Symbolic References that Offer Ecological Insight}

Chander Pahar or Moon Mountain has ample events that could be used to identify the root cause for the environmental crisis. The novel is a real account of the adventures of Shankar, a young Bengali boy, in negotiating the African wildness; this instigates the eco-conscious study of the novel. "In his heart, he wanted to fly, far away to the distant corner of the earth-amidst the most daring and dangerous happenings... He had prepared himself for a life of adventure from his childhood" (Bandyopadhyay, 2007, pp. 4-5). These lines portray Shankar's fondness of wilderness, which is, according to the protagonist, not a place of fear but a sanctuary. Though Shankar feels 
aesthetically drawn towards nature, his quale is tainted with the anthropocentric view of the world. The materialistic consciousness of Shankar is unveiled by his relationship with Alvarez.

The novel begins at a village in India. Shankar is fond of adventure and exploration, but he is compelled by the situation of his family to become a clerk in a saw-mill. But when a letter arrives from his acquaintance, assuring him of a job in Africa, he is relieved. After landing in Africa, Shankar ponders on his dream coming true. He joins as a clerk and storekeeper in a railway construction camp. It is in Africa that the environmental conflicts in the novel arise, the first of which is the human-animal conflict between lions and construction camp inmates. The conflict between humans and animals is a severe problem in many parts of the world, its main reason being man's growing material needs. During the colonial reign, railways, which almost altered or destroyed the habitat of many species, were laid to plunder and transport wealth for the colonial masters.

Shankar's company lays railway tracks connecting Mombasa and Kisumu. It is located in dense grassland, a land of lions. "Listen Roy, don't go out... without a gun... Uganda is the land of lions" (Bandyopadhyay, 2007, p.13). The lion's nature is to hunt for its food, so it hunts the most vulnerable prey: the humans in its territory. Despite intruding the territory of the lion, the humans brand them as blood thirsty man-eaters. When the lion preys on its first human meat, its habitat is destroyed to create a safe place for the humans. "The next day, the long grass was cut clean in a wide swathe around the tents" (Bandyopadhyay, 2007, p.14). In the novel, the above-mentioned part about lions is largely drawn from the personal experiences of John Henry Patterson, a soldier, and author, commissioned by the British East India Company to supervise the construction of railway lines in Kenya. His conduct in dealing with the notorious twin man-eating lions that plagued the Tsavo earned him written felicitation from his workers. These incidents are chronicled in The Man-Eaters of Tsavo (1907). Here, we find the intrusion (laying rail lines) and invasion (killing of the lion) being highly appreciated.

Even in history, the royal hunt is a glorified concept. It is a symbol of pride and power. In the pre-colonial era, the royalties found hunting as a matter of pride and courage. It is continued during the colonial period where the British authorities and also the native Kings hunted to exhibit their power. "In pre-colonial India, tiger hunting was considered a symbol of kingship by the local society." (Hussain, 2010) At the same time, some recent authors venture to re-write the history ecoconsciously. The recent Bollywood movie Manikarnika: The Queen of Jhansi (2019) shows the heroine striking a tiger, which has intruded into the village, with a tranquilizer arrow. She orders her soldiers to cage the tiger and free it in the forest. Tiger, clearly, an endangered species, needs preservation and protection in the contemporary age. When history clearly shows that tiger hunting had been a sport of royal, however, recent writers attempt to induce the perception that hunting down is not valour enough when compared to saving a wild. Eco-consciousness is thus highlighted when the princess cares about the survival of the animal. On the other hand, in Moon Mountain, the lions are killed by the intruders just because the wild species hunts for its food.

In Moon Mountain, the fear for lion resulted in the coolies' hesitation and unwillingness to work, and they even refuse to work far away from the camp. Still, some coolies remain calm, agreeing to work even two kilometres away from the camp-they are the 'Masai tribes', the only fearless people. They are brave because they are in direct relation with nature, they have their methods for survival and they adapt to the harsh environment; in contrast, the other coolies who hail from the safe pod of civilization are hesitant and afraid of the wilderness. The conflict comes to an end when the camp is shifted due to rain and the fear of the man-eating lion. The humananimal conflict is just at its initial stage. The damage and destruction caused by this conflict is a 
grave danger to both the species involved. In reality, with the development of technology, humans have the upper hand, leaving the mere survival of many species under question.

Lions, long celebrated throughout history as the king of the forest for its courage and strength, have now become refugees. Once, they roamed most of Africa and parts of Asia and Europe. Today, they are found only in parts of sub-Saharan Africa, except for a very small population of Asian lions that survive in India's Gir Forest. These lions, spread from the Middle East to India, lost their habitat, and their movement was curtailed to the northern part of India by the $18^{\text {th }}$ century. Due to trophy hunting, deforestation and the rise of the human population, the kings of the forest have shrunk, reduced to refugees in approximately 540 sq miles of Gir forest. Even today, numerous newspaper articles run with titles such as 'Speeding rails kill lions in Gir,' serving as evidence that the insensitive actions of humans are transforming them into an invasive species.

Though environmentalists show interest in iconic species such as lion and tiger, they are a little hesitant to show the same concern towards other critically endangered species. There is a sharp population decline of many vertebrates such as birds, fish, reptiles, and mammals, but a specific cause is yet to be found. The reason for its deterioration is attributed to the global phenomenon. For the decline of snakes, there is consensus, and herpetologists assume that snakes will disappear worldwide for there are no long-term individual-based studies on the snake population. There are no specific predators of the snake; the greatest threat to their survival is habitat loss. In Moon Mountain, Shankar encounters the most reputed and deadliest snake in the world-the black mamba. The novel describes how the snakes' territory is taken away by the protagonist. On leaving the construction company, Shankar finds a job as station master in a small railway station, where he has to stay alone in the middle of the forest. Shankar seems to like the desolated grassland, the mysterious nights, the rustling leaves caught in the night winds, the howling jackals, the roaring lion, and other lurking dangers, the life he wished for.

Shankar sees a huge yellow and brown hooded cobra near him, but it swiftly disappears into the thatched roof. Unlike lions, which are kept away by fire or closed doors; snakes can be hardly stopped; it can come in through crack or hole anytime. He examines the station grounds, finding large holes everywhere, along with some cracks and holes in the walls of the station office and quarters. Sleeping in the station office at night, Shankar wakes up with an instinct of danger, hearing a faint noise in the room. He gropes in the dark for the torch and flashes it; at that instant, he freezes numb with fear and awe looking at the black mamba, rising a metre with its hood midway between the wall and his bed. The torchlight dazes the snake, its eyes burning like two luminous spheres, which captivate Shankar. Somehow, he takes hold of himself, feeling the pain on his hand as he was holding the torch for a long time. As the clock strikes three in the morning, his hands move a little, and the two specks of light disappear. Bemused, Shankar swiftly jumps and unlocks the door, running into the dark. He spends the rest of the night on the platform.

Shankar recounts to the guard about his encounter with the black mamba and gets a coolie from the train to stay with him. He also asks the guard to get him a gun or a revolver on his next trip, also insisting that he get him some carbolic acid. Examining the holes, Shankar understands that "Most of the holes are rat holes. The snake had probably entered them during the day to look for a rat" (34). Shankar and the coolie spend the day examining and sealing all the holes on the ground and walls of the station office and the quarters. Shankar sprinkles carbolic acid all over and around the room. Thus, he usurps the snakes' territory-though it was necessary for his safety, it shows his anthropocentric mindset. In reality, this anthropocentric mindset has led the growing population to invade the territory of the snakes. Snakes are considered malign as they are associated 
with danger. Most of the people do not realize the role of snakes in the ecosystem; being the middleorder predator, snakes kill rats and mice, acting as a pest controller. Rats and mice are bearers of disease and destroyers of crops; they also reproduce extensively; snakes are the checks, acting as a key component to bring balance in nature. Snakes are shy creatures and try to escape when confronted; they become defensive when encountered and raise their heads or their body. The conflict between humans and snakes arise due to the fear among both species; snakes mostly attack when the attacker persists in killing or capturing it. When they are left alone, snakes present little or no danger to people. According to the International Union for the Conservation of Nature (IUCN), which released the red data book, nearly $28 \%$ of the snake species are threatened. Snakes do not have specific predators; encroachment and habitat destructions are the significant reasons for its decline.

Shankar carries on with his routine work at the station. Then, he faces another major problem, scarcity of water; the water supplied by the train is hardly enough for cooking and drinking, and the water at the local well has dried up. There is a lake, Shankar comes to know, three miles away from the station, and lured by the thought of fishing and bathing, he goes there. He begins to frequent the lake. The African summer is extremely fierce, making it impossible for Shankar to go out after nine in the morning. On such a hot day, Shankar finds Alvarez, an old explorer in search of the diamond mine in Richtersveldt. After hearing to Alvarez's story and receiving his map in which he has roughly marked the location of the mountains where the yellow diamonds can be found, Shankar's materialistic desires are rekindled. Thus, Shankar gives up his post as station master and joins Alvarez. Life as an explorer is more complicated, though the young mind seems to enjoy the scene of the wild, which he was always fascinated. The search for the diamond mine takes them through the dark and dense jungles of Africa. Though Shankar is not entirely obsessed with yellow diamonds, he is astonished by nature; whereas, Alvarez is obsessed only with the thought of finding the mine. Shankar learns various skills from Alvarez such as bushcraft and quick shot firing techniques to tactically handle problems and to stay alert round the clock.

Mining is a serious ecological problem, has numerous adverse effects on almost every environmental element such as water, air, and soil. It also causes noise pollution, affecting the wildlife by fragmenting their habitat and resulting in its loss. Most of the environmentalists show concern about the problems mentioned above, but mostly they underestimate or ignore the impact of mining on people living in the nearby areas or locality. Mining displaces them to other areas, and the poor and the vulnerable are mostly its direct victims.

Shankar and Alvarez encounter the Matabele tribe in the Rhodesian Veldt. Alvarez orders Shankar to be armed, and Shankar thinks that they are going to attack the three tribes. But instead, Alvarez offers them tea and dinner. Alvarez is skilled in tackling the tribes. Alvarez's statement on the Matabele tribes gives us a clear picture of the tribal life. The Matabele tribes, he explains, are fierce, and he will use guns only if they are not satisfied with the food he has offered. The veldt, we come to know, belongs to their tribal king, and these tribes are against the exploration of the diamond mine. They are dependent on the forest and its products-utilization but not the exploitation of the resource. But the greed of the money-seeking civilized society has intrigued the tribes for exploiting the natural resources. The recalcitrant are side-lined by the social classes, and the recalcitrance of the Matabele tribes would have led to their genocide in the 1980's.

The novel also shows the many African tribes like Swahilis, Maasis, Somalis, and Zulus. The tribes live in harmony and one with nature. They are brave, adventurous, believers of superstitions 
and are undeterred by the animals. The tribes depend on forest resources for their livelihood, and they never exploit or harm the ecosystem. The tribes worship nature and believe that their life is completely at the mercy of nature. The boundaries for the tribes are often volatile; it is where they carry out their activities like hunting and gathering which they tend to preserve. But Alvarez is of the opinion that the tribes control and show authority over the forest territory, which clearly suggests his colonial mindset.

We find the consciousness of Shankar oscillating between materialism and aestheticism. Shankar seems to lose himself in the marvels of nature, frequently captivated by the beauty of Africa, his dreamland. The stars in the sky make him stay awake all night; he even ignores the chillness just to gaze the sky. "Sleep deserted Shankar's eyes. Captivated by this dreamland of beauty, he would stay awake all night, ignoring the chill in the air" (Bandyopadhyay, 2007, p. 67). He is always tempted to stop and enjoy nature, and every time his memory returns to his hometown and his life over there: "In another far corner of the sky the Saptarishi would also have risen above a small village in Bengal, and so would that small sliver of a waning moon in the dark night..." (Bandyopadhyay, 2007, p. 67).

After listening to the story and getting the map from Alvarez, Shankar plans his next course of action: "Why don't you try me and find out whether or not I have the courage?" (54) The dangers of the forest do not dampen his spirit, but encouraged his desire to find the diamond mine. Unintentionally, Shankar's materialistic attitude is revealed through this incident. Throughout the novel he shows a dilemma of switching towards materialism and aesthetics, his materialistic desires were always overshadowed by his sense of aesthetics.

When Shankar is drained of energy, he doubts and questions Alvarez's materialistic motives:

In this strange country, across the tops of the uncharted mountains covered with dense forests full of bloodthirsty beast, why was he running towards some undiscovered diamond mine...? Who was Alvarez? Why did he listen to him and come this far? He had no need for diamond. The Straw - thatched huts of his village in Bengal, the shady and sleepy village paths, the little stream, the familiar chirping of birds... No diamond mine of Africa is precious than that!"(Bandyopadhyay, 2007, p. 91)

Shankar's spirit of adventure and aestheticism returns to him when the moon is high and when the nature enchants him with its beauty:

$[\mathrm{H}]$ is mood changed late at night ... That unearthly moonlit night beggared description! Shankar wasn't in this world anymore... He didn't want to go back anywhere; he had no need for diamonds or for wealth. He had become the inhabitant of this lotus - white realm of the gods... Far away from human habitation... It was a rare sight and rarer was the chance to be part of it. (Bandyopadhyay, 2007, p. 91).

But the materialistic endeavour of Alvarez and Attileo Gatti's diamond has infected him to such an extent that his aesthetic mindset is suppressed altogether. The young boy who has endured all the hardships of the wilderness with some aesthetic pleasure is not the same at the end. He is now determined to form a company and return to the faraway Richtersveld Mountain to explore the diamond mines:

"He would go back to Africa... He would spend some time in his country. Then he would try and form a company, and return to the faraway Richtersveld Mountain to search for the diamond mine. He was determined to find it". (Bandyopadhyay, 2007, p. 171) 
Shankar has a great love for nature, but when the diamonds were in his possession, he wishes to return to the jungle, not with the spirit of enjoying nature, but with the determination to find the diamond mine. After his turmoil and endurance through the tremendous African Jungle, Shankar's attitude towards life completely changes. He is determined to remain unaffected by happiness or misery and becomes brave. But the anthropocentric and materialistic mindset of the society, the books he read and the education he had, has influenced Shankar to a great extent, rendering him insensitive towards nature. Similarly, during the industrial revolution and colonisation, people turned insensitive and lost their compassion for nature. Moon Mountain depicts many of the root causes for the environmental crises such as human-animal conflict, mining, and human insensitivity towards nature. The lack of sensitivity remains the primary cause, leading to environmental degradation. But options are always there; humans have an opportunity to rectify this situation through a fair use of natural resources and creating awareness among people, especially the youth.

\section{Conclusion}

Moon Mountain is not just a story of adventure of any young adult, but a detailed narration of the initial phase of modern civilization Shankar's humanistic and exhilaration for adventure takes through multiple forms of nature. Through the course of his adventure, Shankar adapts to difficult situations and grows out as a courageous young man with great determination. The novel gives an ecological insight on nature being exploited by human in the name of growth and civilization. Colonization led to control of natural resources for want of wealth and power. The non-availability and enormous need for resources as a result of Industrial revolution turned humans insensitive towards nature. The lack of sensitivity has led to depletion of resources and environmental degradation. The critical tracing of human insensitivity towards nature will help people build a harmonious relationship with nature. The hamartia of the mankind is the anthropocentric attitude and his insensitivity towards nature. Human's desire for wealth and sophisticated life has led to the depletion of natural resource. Humans occupying the top position on the pyramid exploited the habitat of the species down the pyramid without understanding the significance of those species in maintaining the balance of nature. Though imperialism and colonial impacts had left a deep foot print on the environment, the immediate environmental calamities have made people aware of how far it is prerequisite to be conscious of being eco-conscious. This study brings out how the colonial legacies continue to influence the contemporary environmental challenges and discusses the literary relationships between nature and youth influence readers' attitudes towards the contemporary anxieties such as climate change and related environmental crises.

\section{References}

Bandyopadhyay, B. (2007). Moon Mountain (Sinha, Pradeep, Trans.). Hyderabad: Orient Longman. 
Brundtland, G. (1987). Report of the World Commission on Environment and Development: Our Common Future. [online] Available at: http://www.un-documents.net/our-common-future.pdf [Accessed 27 Nov. 2017].

Burnouf, L. (2004). Global awareness and perspectives in global education. Canadian Social Studies,38(3), 112.

Chakravarty, B. (2003) "Bibhutibhusan Bandyopadhyay: Geographical Imagination and Imaginary Geography.” Indian Literature, vol. 47, no. 6 (218), pp. 178-191. JSTOR, www.jstor.org/stable/23341081.Accessed 11 Apr. 2020.

Daniels, C. (2006). "Literary Theory and Young Adult Literature: The Open Frontier in Critical Studies. "The ALAN Review, 33(2), pp.78-82.

Dalai, D. R. (2011). Destination Moon Mountain: A Foray into the World of Young Adult Literature. Muse India, 39.

Davis, T. (1997). "On the question of integrating young adult literature into the mainstream." The ALAN Review, 24(3), 5-8.

Government of India. Ministry of Environment and Forests. (2014). National Mission for a Green India (Under the National Action Plan on Climate Change). MOEF.

Glotfelty, C. and Harold Fromm. (1996). The Ecocriticism Reader: Landmarks in Literary Ecology (1996th ed). Chicago: University of Georgia Press.

Hussain, S. (2010). Sports-hunting, Fairness and Colonial Identity: Collaboration and Subversion in the Northwestern Frontier Region of the British Indian. Conservation and Society, 8(2), p.112.

Ingram, A., Marshall, I., Philippon, D., \& Sweeting, A. (Eds.). (2007). Coming into Contact: Explorations in Ecocritical Theory and Practice. Athens; London: University of Georgia Press. Retrieved from http://www.jstor.org/stable/j.ctt46ndvw

Ingram, A., Marshall, I., Philippon, D., \& Sweeting, A. (2007). Thinking Our Life in Nature. In Ingram, A., Marshall, I., Philippon, D., \& Sweeting, A. (Eds.) Coming into Contact: Explorations in Ecocritical Theory and Practice (1-14). Athens, Georgia: University of Georgia Press.

Mumba, M. (2008). Unraveling the 'Mountains of the Moon'[online] www1.uneca.org.Available at: http://www1.uneca.org/Portals/acpc/documents/cc_gender/UnravellingtheMountainsofthemoon.p df [Accessed 2 Nov. 2015].

Murphy, P. (2009). Ecocritical Explorations in Literary and Cultural Studies: Fences, Boundaries, and Fields. Lanham: Lexington Books.

The Times of India. (2014, 4 June). Railways Agrees to Limit Train Speed near Gir Forest to Prevent Accidents with Asiatic Lions. Retrieved from https://timesofindia.indiatimes.com/home/environment/flora-fauna/Railways-agrees-to-limittrain-speed-near-Gir-forest-to-prevent-accidents-with-Asiatic-lions/articleshow/36046805.cms

Thompson, A. (2009). "Responsibility for the End of Nature: Or, How I Learned to Stop Worrying and Love Global Warming." Ethics and the Environment. 14(1), 79-99. 